\title{
Kewenangan Mediator Pegawai Negeri Sipil Dalam Penyelesaian Perselisihan Hubungan Industrial
}

\author{
Sapta Imtinan Akmal, Juwita Sarri, Yanto Yunus \\ imtinanakma1602@gmail.com \\ Suarez YY \& Associates
}

\begin{abstract}
Keywords: $\quad$ Abstract
Authority; $\quad$ Authority is a legitimation for every state apparatus activity, include the mediator of industrial Mediator; dispute resolution. The mediator authority is described in Peraturan Menteri Ketenagakerjaan Industrial Dispute No.17/2014. In this act, described that mediator has an obligation to solve industrial dispute in Resolution. 30 days. But, in case, the limit of the process is over 30 days. In this research, will be describe is the public emlopyee mediator in indutrisal dispute resolution still have legitimate to do the mediation more than 30 days. The approach that used in this resedarh is conceptual approach dan the statute approach.The result of the research is the mediator authority is a attribution, which authority is born from the statute on the settlement of industrial relations disputes. So that will make the legal impact if its authority is not used based on the rules. The legal impact from this problem are, besides the administrative sanction, also impacted to the legal product, make these legal product, either the judicial act or the collective bargaining agreement illegitimate, which can make the negative impact for every parties in industrial dispute resolution. But, there is a phrase without the illegitimate reason, which need to reinterpreted again and make the mediator whom do their authority more than 30 days is not be able to be sanctioned.
\end{abstract}

\section{Kata Kunci: \\ Kewenangan; Mediator; Penyelesaian Perselisihan Hubungan Industrial.}

\begin{abstract}
Abstrak
Kewenangan merupakan dasar setiap tindakan aparatur pemerintahan, termasukmediator penyelesaian hubungan industrial. Kewenangan mediator dijelaskan dalam Peraturan Menteri Ketenagakerjaan dan Transmigrasi Nomor 17 Tahun 2014. Di dalam Peraturan tersebut dijelaskan bahwa Mediator berkewajiban untuk menyelesaikan perselisihan hubungan industrial dalam jangka waktu paling lama 30 hari. Namun, tak jarang, batas waktu penyelesaian tersebut melebihi 30 hari. Dalam penelitian kali ini, akan dibahas apakah mediator pegawai negeri sipil pada dinas ketenagakerjaan masih berwenang melakukan mediasi setelah melewati batas waktu 30 hari kerja yang telah ditentukan secara limitatif tersebut. Pendekatan penelitian yang digunakan adalah pendekatan konseptual dan pendekatan perundang-undangan. Hasil penelitian diperoleh bahwa kewenangan mediator pegawai negeri sipil dalam penyelesaian perselisihan hubungan industrial merupakan wewenang atribusi yang mana wewenang tersebut lahir dari Undang-Undang Penyelesaian Perselisihan Hubungan Industrial. Kewenangan Mediator Penyelesaian Perselisihan Hubungan Industrial terikat pada batas masa tertentu, batas tertentu dan terikat pada ketentuan hukum tertentu, sehingga akan membawa implikasi yuridis apabila tidak dijalankan sebagaimana mestinya. Implikasi yuridis dari lewat batas waktu ini, selain pengenaan sanksi adminitratif bagi mediator, juga berdampak pada produk hukum yang dihasilkan, baik risalah maupun perjanjian bersama, yaitu menyebabkan produk hukum tersebut tidak sah. Keadaan ini tentunya malah akan membuat kerugian bagi para pihak yang bersengketa dalam Penyelesaian Perselisihan hubungan industrial. Namun, masih terdapat frasa tanpa alasan yang sah, yang mana frasa tanpa alasan yang sah ini membuat tidak bisanya pengenaan sanksi adminitratif kepada mediator yang lewat waktu selama 30 hari dalam menjalankan kewenangannya.

Copyright (C) 2022 Sapta Imtinan Akmal, Juwita Sarri, Yanto Yunus.

Published in Media Iuris. Published by Universitas Airlangga, Magister Ilmu Hukum. (cc) (i)
\end{abstract}


Sapta Imtinan, dkk: Kewenangan Mediator Pegawai...

\section{Pendahuluan}

Hubungan kerja adalah suatu hubungan hukum yang dilakukan oleh minimal dua subjek hukum mengenai suatu pekerjaan. Subjek hukum yang melakukan hubungan kerja adalah pengusaha/pemberi kerja dengan pekerja/ buruh. Hubungan kerja merupakan inti dari hubungan indusrial. Dalam ketentuan Pasal 1 angka 14 Undang-Undang No. 13 Tahun 2003 Tentang Ketenagakerjaan menyebutkan hubungan kerja adalah hubungan antara pengusaha dengan pekerja/buruh berdasarkan perjanjian kerja, yang mempunyai unsur pekerjaan, upah dan perintah. Ketiga unsur hubungan kerja tersebut bersifat kumulatif, hal tersebut yang membedakan hubungan kerja dengan hubungan lain.

Lany Ramli dalam bukunya berjudul Hukum Ketenagakerjaan, mengatkan bahwa diskursus tentang ketenagakerjaan bagaikan membahas dua kutub yang berseberangan. Kutub Utara dan Selatan atau Pihak buruh dan majikan. Dua pihak yang mempunyai kepentingannya sendiri dan pastinya kepentingan tersebut saling bertentangan satu sama lain. ${ }^{1}$ Dalam hubungan kerja tentu menimbulkan conflict of interest antara pengusaha dengan pekerja/buruh, baik yang terjadi pada masa before employment, during employment, maupun after amployment.

Dalam hukum ketenagakerjaan yang menjadi objek sengketa hanyalah mencangkup 4 (empat) hal. Pertama, Perselisihan Pemutusan Hubungan Kerja, kedua, perselisihan hak, ketiga, perselisihan kepentingan, dan keempat perselisihan antar serikat pekerja/serikat buruh. Objek sengketa inilah yang dinamakan sengketa hubungan industrial dan diselesaikan melalaui proses penyelesaian perselisihan hubungan industrial sebagaimana amanah Undang-Undang No. 2 Tahun 2004 Tentang Penyelesaian Perselisihan Hubungan Industrial.

Dalam proses penyelesaian perselisihan hubungan industrial penting kiranya mengetahui tahapan proses penyelesaian perselisihan hubungan industrial yang dimulai dengan tahapan Bipartite yang melibatkan pekerja/ buruh dengan pengusaha, tahapan Tripartite yang melibatkan Mediator dinas

\footnotetext{
${ }^{1}$ Lanny Ramli, Hukum Ketenagakerjaan (Airlangga University Press 2008).[5].
} 
ketenagakerjaan, sampai dengan tahapan Pengadilan Hubungan Industrial sebagai upaya terakhir para pihak yang bersengketa melakukan penuntutan hak. Dalam kesempatan ini, pembahasan penulis diarahkan khusus berkaitan dengan proses penyelesaian secara Mediasi yang melibatkan mediator pengawai negeri sipil (PPNS) dalam penyelesaian perselisihan hubungan industrial. Sebab, terkadang proses penyelesaian perselisihan hubungan industrial pada tahapan Mediasi yang melibatkan Mediator PPNS pada Dinas Ketenagakerjaan sangat menguras waktu yang cukup Panjang dan berlarut-larut, terlebih keterbatasan mediator PPNS pada instansi Dinas Ketanagakerjaan tersebut menjadi faktor utama keterlambatan proses mediasi.

Begitupun dengan letak keberadaan geografis para pihak yang sangat jauh membuat proses mediasi menjadi tertunda karena salah satu pihak tidak hadir atau berhalangan untuk hadir. Kondisi inilah yang membuat proses penyelesaian perselisihan hubungan industrial pada tahap Mediasi menyita banyak waktu. Padahal jika merujuk pada ketentuan Undang-Undang No. 2 Tahun 2004 Tentang Penyelesaian Perselisihan Hubungan Industrial jo Peraturan Menteri Tenaga Kerja RI No. 17 Tahun 2014 Tentang Pengangkatan dan Pemberhentian Mediator Hubungan Industrial Serta Tata Cara Kerja Mediasi telah memberikan limitatif waktu dalam proses penyelesaian perselisihan hubungan industrial melalui mediasi selambat-lambatnya adalah 30 hari.

Hal ini senada dengan ketentuan Pasal 15 Permenaker No. 17 Tahun 2014 tersebut di atas secara tegas mengatur proses penyelesaian melalui mediasi harus sudah selesai dalam waktu paling lambat 30 (hari) kerja sejak diterimanya pelimpahan penyelesaian perselisihan kepada mediator. Hal ini menimbulkan pertanyaan mendasar terkait proses penyelesaian perselisihan hubungan industrial melalui tahapan mediasi tersebut ternyata melebihi batas waktu yang telah ditentukan. Sehingga isu hukum yang diangkat pada tulisan ini adalah apakah mediator pegawai negeri sipil dinas ketenagakerjaan masih berwenang melakukan proses mediasi yang telah melebihi dari batas waktu 30 (tiga puluh) hari kerja sebagaimana ditentukan dalam Undang-Undang No. 2 Tahun 2004 
Sapta Imtinan, dkk: Kewenangan Mediator Pegawai...

Tentang Penyelesaian Perselisihan Hubungan Industrial jo Peraturan Menteri Tenaga Kerja RI No. 17 Tahun 2014 Tentang Pengangkatan dan Pemberhentian Mediator Hubungan Industrial Serta Tata Cara Kerja Mediasi.

\section{Metode Penelitian}

Jenis Penelitianyang diggunakanadalah penelitian hukum, denganmenggunakan pendekatan undang-undang (Statute approach) yakni menelah semua undang-undang dan regulasi yang berkaitan dengan isu hukum. ${ }^{2}$ Pendekatan konseptual (Conceptual Approach) menelaah terkait prinsip atau pandangan yang dikemukakan oleh ahli atau doktirn hukum yang terkenal, serta konsep-konsep yang tidak terdapat dalam undangundang ataupun di dalam putusan-putusan pengadilan. ${ }^{3}$

\section{Konsep Kewenangan}

Kewenangan merupakan konsep yang sangat penting dalam penyelenggaraan negara dan pemerintahan. Terlebih, bagi negara Indonesia yang menganut asas negara hukum, kewenangan yang diberikan oleh undangundang merupakan substansi dan legitimasi bagi penyelenggaraan negara. Kewenangan merupakan substansi asas legalitas Het vermogen tot het verichten van bepaalde rechtshandelingen, yaitu kemampuan untuk melakukan tindakan hukum tertentu. ${ }^{4}$ H.D. Stout menjelaskan mengenai kewenangan: "Bevoegheid is een begrip uit het bessturlijke organisatie recht, wat kan woden omschreven als et geheel van regels dat betrekking heeft op de verkrijging en uitoefening van bestuursrechtelijke bevoegdheden door publiekrechttelelijke rechtssubjecten in het bestuursrechtelijke rechtsverkeer. ${ }^{5}$ (Kewenangan adalah pengertian yang berasal dari hukum organisasi pemerintahan, yang dapat dijelaskan sebagai keseluruhan aturan-aturan yang berkenaan dengan perolehan dan penggunaan wewenang oleh subjek hukum publik di dalam lapangan hukum publik).

\footnotetext{
${ }^{2}$ Peter Mahmud Marzuki, Penelitian Hukum (Kencana Pranadamedia 2005).[133].

3 ibid.[178-180].

${ }^{4}$ Ridwan HR, Hukum Administrasi Negara (PT Raja Grafindo Persada 2013).[98].

${ }^{5}$ ibid.
} 
Lebih lanjut. H.D.Stout, dengan menyitir pendapat Goorden, mengatakan bahwa wewenang adalah "het gehel van rechten en plichten dat hetzij expliciet door de wetgever aan publiekrechtelijke rechtsubjectes is toegekend" (Keseluruhan hak dan kewajiban yang secara eksplisit diberikan oleh pembuat undang-undang kepada subjek hukum publik). Menurut F.P.C.L. Tonnaer "Overheidsbevoegdheid wordt in dit verband opgevat als het vermogen om positief recht vast de stellenan Aldus rechtsbbetrekkingen tussen burgers onderling en tussen overhead en te scheppen (Kewenangan pemerintah dalam kaitan ini dianggap sebagai kemampuan untuk melaksanakan hukum positif dan dengan begitu, dapat diciptakan hubungan hukum antara pemerintah dengan warga negara). Kewenangan memiliki kedudukan penting dalam kajian Hukum Tata Negara dan Hukum Administrasi Negara. Begitu pentingnya kedudukan kewenangan ini, sehingga F.A.M. Stoink dan J.G.Steenbeek menyebut konsep inti dalam Hukum Tata Negara dan Hukum Administrasi Negara "Het begrip bevoegdheid is da nook een kernbegrip in het staats-en administratief recht. ${ }^{6}$ Menurut Bagir Manan, kewenangan dalam bahasa hukum tidak sama dengan kekuasaan (macht). Kekuasaan hanya menggambarkan hak untuk berbuat dan tidak berbuat, sementara kewenangan dalam hukum berarti hak sekaligus kewajiban (rechten en plichten). Hak mengandung pengertian kekuasaan untuk mengatur sendiri (zelfregelen) dan mengelola sendiri (zelfbestuuren), sedangkan kewajiban secara horizontal berarti kekuasaann untuk menyelenggarakan pemerintahan sebagaimana mestinya. Vertikal berarti kekuasaan untuk menjalankan pemerintahan dalam satu tertib pemerintahan secara keseluruhan. ${ }^{7}$

Seiring dengan dianutnya paham negara hukum, maka kewenangan harus bersumber dari peraturan perundang-undangan yang ada (konstitusi), supaya dalam pelaksanaannya, kewenangan tersebut menjadi kewenangan yang sah. Secara teoritis, Van Wijk membagi kewenangan pejabat (organ) negara ke dalam beberapa jenis, sebagai berikut: 
a. Atribusi, yaitu pemberian kewenangan pemerintah oleh pembuat undangundang kepada organ pemerintahan. Pada atribusi, kewenangan yang diperoleh bersifat asli berasal dari peraturan perundang-undangan. Penerima wewenang dalam atribusi dapat menciptakan kewenangan baru atau memperluas kewenangan yang sudah ada sebelumnya, dengan tanggungjawab pelaksaan wewenang secara ekstern dan intern yang diatribusikan sepenuhnya kepada penerima kewenangan

b. Delegasi, yaitu pelimpahan kewenangan dari suatu organ pemerintahan kepada organ pemerintahan lainnya. Pada delegasi, tidak ada penciptaan wewenang. Yang ada hanyalah pelimpahan wewenang. Tanggungjawab yuridis tidak berada pada pemberi kewenangan, melainkan telah beralih kepada penerima kewenangan (delegans).

c. Mandat. Mandat terjadi ketika organ pemerintahan mengizinkan kewenangannya oleh organ lain atas namanya.

\section{Kewenangan Mediator Hubungan Industrial}

Mediator merupakan pihak dalam penyelesaian hubungan industrial yang sangat esensial. Keberadaan seorang mediator menentukan jalannya proses penyelesaian hubungan industrial yang sedang dihadapi oleh pihak-pihak yang berperkara. ${ }^{8}$ Mengenai kewenangan mediator, setidaknya ada beberapa peraturan perundang-undangan yang dapat dijadikan sebagai acuan. Merujuk kepada Undang-Undang Nomor 2 Tahun 2004 tentang Penyelesaian Perselisihan Hubungan Industrial, definisi mediator adalah pegawai pemerintah pada instansi ketenagakerjaan yang memenuhi syarat-syarat sebagai mediator yang ditetapkan oleh Menteri untuk bertugas melakukan mediasi, yang bertugas memberikan anjuran tertulis kepada para pihak yang berselisih untuk menyelesaikan perselisihan hak, perselisihan kepentingan, perselisihan pemutusan hubungan kerja, dan perselisihan antar serikat pekerja/ serikat buruh dalam satu perusahaan.

8 Lia Lestari, 'Peran Mediator Dalam Penyelesaian Perselisihan Hubungan Industrial' (Program Pascasarjana Universitas Medan Area 2019).[24]. 
Kewenangan mediator sendiri, diterangkan dalam Peraturan Menteri Tenaga Kerja dan Transmigrasi Republik Indonesia Nomor 17 Tahun 2014 Tentang Pengangkatan dan Pemberhentian Mediator Hubungan Industrial serta Tata Kerja Mediasi. Pasal 10 Ayat (1) Peraturan Menteri Tenaga Kerja dan Transmigrasi Republik Indonesia Nomor 17 Tahun 2014, merinci kewenangan mediator dalam hubungan industrial sebagai berikut:

1. Meminta para pihak memberikan keterangan secara lisan dan tertulis;

2. Meminta surat-surat dan dokumen yang berkaitan dengan perselisihan dari para pihak;

3. Menghadirkan saksi atau saksi ahli dalam mediasi apabila diperlukan; ${ }^{9}$

4. Meminta dokumen dan surat-surat yang diperlukan dari Dinas Provinsi dan Dinas Kabupaten/Kota atau lembaga terkait dan;

5. Menolak kuasa para pihak yang berselisih apabila tidak memiliki surat kuasa khusus. ${ }^{10}$

Mediator dalam penyelesaian hubungan industrial dapat berkedudukan di Kementerian, Dinas Kabupaten/Kota, maupun di Dinas Provinsi. Dalam menjalankan tugas dan kewenangannya, mediator memiliki pula beberapa kewajiban. Kewajiban tersebut, antara lain adalah sebagai berikut:

1. Memanggil para pihak yang berselisih untuk diambil dan didengar keterangan yang diperlukan;

2. Mengatur dan memimpin mediasi;

3. Membantu dan membuat perjanjian bersama, apabila mediasi berhasil tercapai

4. Membuat anjuran tertulis apabila dalam hal mediasi tidak tercapai; ${ }^{11}$

5. Membuat risalah penyelesaian perselisihan hubungan industrial;

6. Membuat laporan hasil penyelesaian perselisihan hubungan industrial. ${ }^{12}$

Berdasarkan pemaparan Pasal 10 Peraturan Menteri Tenaga Kerja dan Transmigrasi Nomor 17 Tahun 2014, kita dapat mengetahui bahwa kewenangan mediator dalam proses penyelesaian perselisihan hubungan industrial hanyalah terbatas pada ranah non-litigasi (di luar pengadilan).

${ }^{9}$ Asri Wijayanti, Hukum Ketenagakerjaan Pasca Reformasi (2016).[187].

${ }^{10}$ Andry Sugiantari Solechan, Suhartoyo, ‘Penyelesaian Perselisihan Hubungan Industrial melalui Mediasi di Dinas Tenaga Kerja dan Transmigrasi Kota Semarang' (2016) 5 Diponegoro Law Review <https://www.neliti.com/id/publications/19005/penyelesaian-perselisihan-hubunganindustrial-melalui-mediasi-di-dinas-tenaga-ke>.[7].

11 ibid.

12 Andry Sugianti et al, 'Penyelesaian Perselisihan Hubungan Industrial Melalui Mediasi di Dinas Tenaga Kerja dan Transmigrasi Kota Semarang’ (2016) 5 No. 2 http:/ / www.ejournal-s1.undip. ac.id/index.php/dlr/ 7.[8]. 
Sapta Imtinan, dkk: Kewenangan Mediator Pegawai...

\section{Bentuk Penyelesaian Perselisihan Hubungan Industrial Melalui Nonlitigasi}

Untuk memahami karakteristik kewenangan mediator, terlebih dahulu kita harus memahami konsep-konsep penyelesaian yang ada dalam perselisihan hubungan industrial.Dalam penyelesaian perselisihan hubungan industrial, setidak-tidaknya di kenal beberapa metode penyelesaian, baik secara litigasi maupun Non Litigasi. Beberapa di antaranya, yang merupakan jalur non-litigasi diantaranya yaitu perundingan bipartit, konsiliasi, arbitrase, dan mediasi.

1. Perundingan Bipartit

Sebagaimana dijelaskan dalam Pasal 3 Ayat (1) Undang-Undang Penyelesaian Hubungan Industrial, wajib dilakukan terlebih dahulu melalui perundingan bipartit secara musyawarah mufakat. Lebih lanjut, dalam penjelasan pasal ini ditegaskan bahwa perundingan bipartite adalah perundingan antara pengusaha atau gabungan pengusaha dan pekerja/ buruh atau serikat pekerja/serikat buruh atau antara serikat pekerja/serikat buruh dan serikat pekerja/serikat buruh yang lain dalam satu perusahaan yang berselisih. ${ }^{13}$ Lingkup penyelesaian melalui perundingan bipartite meliputi empat jenis perselisihan hubungan industrial, yaitu perselisihan hak, perselisihan kepentingan, perselisihan pemutusan hubungan kerja dan perselisihan antara serikat pekerja/serikat buruh dan serikat pekerja/ serikat buruh lainnya dalam satu perusahaan. ${ }^{14}$ Penyelesaian secara bipartite sering disebut sebagai negosiasi. Negosiasi adalah upaya penyelesaian sengekta oleh para pihak tanpa melibatkan pihak lain dengan tujuan mencapai kesepakatan bersama atas dasar kerjasama yang harmonis dan kreatif. ${ }^{15}$ Karena sifat negosiasi yang merupakan komunikasi dua arah tanpa keterlibatan pihak ketiga, maka ada beberapa hal yang harus diperhatikan dalam perundingan Bipatrit, yang aman dijabarkan oleh Garry Goodpaster sebagai berikut:

${ }^{13}$ Abdul Khakim, Aspek Hukum Penyelesaian Perselisihan Hubungan Industrial (Citra Aditya Bakti 2015).[110].

${ }^{14}$ Abdul Khakim, Aspek Hukum Penyelesaian Perselisihan Hubungan Industrial (2005).[10].

${ }^{15}$ Ari Hernawan, Penyelesaian Sengketa Hubungan Industrial (UII Press 2018).[7]. 

a. Pola tawar menawar;
b. Kekuatan tawar menawar;
c. Strategi tawar menawar.

Dengan memperhatikan pendapat Goodpaster, maka perundingan bipartite akan sulit mencapai hasil yang terbaik bagi pekerja dikarenakan kekuatan tawar pekerja lebih lemah dibandingkan pengusaha. Negara berada di luar pihak, sehingga peran pelindung pihak pekerja tidak ada sama sekali. Pekerja yang posisi tawarnya lemah harus membuat sendiri pola strategi perundingannya. ${ }^{16}$ Jika musyawarah atau negosisasi antara pekerja dan pengusaha berhasil tercapai kesepakatan, maka dibuat perjanjian bersama yang ditandantangani oleh kedua belah pihak yang bersifat mengikat dan dapat dilaksanakan. Perjanjian Bersama tersebut wajib didaftarkan melalui Pengadilan Hubungan Industrial pada Pengadilan Negeri di wilayah para pihak mengadakan Perjanjian Bersama. Apabila salah satu pihak tidak memenuhi ketentuan dalam Perjanjian Bersama, maka pihak yang dirugikan dapat meminta permohonan eksekusi pada Pengadilan Hubungan Industrial di wilayah para pihak menandatangani Perjanjian Bersama. ${ }^{17}$

\section{Perundingan Tripartit}

\section{a. Konsiliasi}

Konsiliasi adalah penyelesaian perselisihan kepentingan, perselisihan PHK dan perselisihan antara serikat pekerja/serikat buruh hanya dalam satu perusahaan melalui musyawarah yang ditangani atau ditengahi oleh konsiliator yang netral. Yang menjadi pihak penengah dalam konsiliasi adalah kosiliator, yang mana merupakan pihak ketiga di luar pegawai dinas ketenagakerjaan, yang terdaftar pada instansi yang bertanggungjawab di bidang ketenagakerjaan kabupaten/kota yang wilayah kerjanya meliputi tempat di mana buruh/pekerja bekerja. ${ }^{18}$ Para pihak yang memilih jalan

\footnotetext{
16 ibid.

17 ibid.

${ }^{18}$ Pujio Ugo, Hukum Acara Penyelesaian Perselisihan Hubungan IndustriaL (Sinar Grafika 2011).[75].
} 
konsiliasi harus membuat pernyataan secara tertulis. Hal ini dilakukan untuk menjawab pertanyaan yang diajukan oleh instansi ketenagakerjaan setelah para pihak mencatatkan perselisihannya. Setelah konsiliator menerima permintaan tertulis dari para pihak yang berselisih, maka dalam 7 hari kerja sudah harus mengadakan penelitian tentang duduk perkara dan pada hari ke-8 sudah dimulai sidang konsiliasi pertama. Sidang dipimpin oleh konsiliator tunggal atau majelis.

Konsiliator menyelesaikan tugasnya dalam waktu 30 hari kerja sejak menerima permintaan tertulis dari para pihak. ${ }^{19}$ Dalam konsiliasi, apabila tidak tercapai kesepakatan maka konsiliator membuat anjuran tertulis kepada para pihak dan para pihak harus memberikan anjuran terulis untuk menerima atau menolak anjuran tertulis tersebut. Apabila para pihak menerima anjuran tertulis, maka konsiliator akan membantu para pihak membuat perjanjian bersama untuk didaftarkan ke pengadilan hubungan industrial untuk mendapatkan akta bukti pendaftaran. ${ }^{20}$

b. Arbitrase

Arbitrase hubungan industrial adalah penyelesaian perselisihan kepentingan dan peneyelesaian perselisihan antar serikat buruh hanya dalam satu perusahaan di luar pengadilan hubungan industrial melalui kesepakatan tertulis dari para pihak yang berselisih untuk menyerahkan penyelesaian kepada arbiter yang putusannya mengikat para pihak dan bersifat final. ${ }^{21}$

Pada awal arbitrase, arbiter wajib menawari para pihak perdamaian. Dalam penyelesaian melalui arbitrase, apabila tercapai perdamaian, maka arbiter wajib membuat akta perdamaian yang ditandatangani para pihak. Akta tersebut kemudian didaftarkan ke Pengadilan Hubungan Industrial agar memperoleh kekuatan eksekutorial. ${ }^{22}$

\footnotetext{
19 ibid.[76].

${ }^{20}$ ibid.[77].

${ }^{21}$ Abdul R Budiono, Hukum Perburuhan (2009).[224].

22 ibid.[225].
} 
c. Mediasi

Mediasi adalah penyelesaian perselisihan hak, perselisihan kepentingan, perselisihan pemutusan hubungan kerja dan perselisihan antar serikat pekerja/buruh hanya dalam satu perusahaan melalui musyawarah ditengahi oleh seorang atau mediator yang netral. Dalam hal tercapai kesepakatan dalam proses mediasi, maka mediator membuat perjanjian bersama untuk ditandatangani dan didaftarkan di Pengadilan Hubungan Industrial. ${ }^{23}$ Tugas dan fungsi mediator sendiri, sebagaimana sudah dijelaskan sebelumnya, diatur dalam Peraturan Menteri Ketenagakerjaan Nomor 17 Tahun 2014, yaitu sebagai berikut:

1) Memanggil para pihak yang berselisih untuk dipanggil dan didengarkan keterangan yang diperlukan;

2) Memanggil para pihak yang berselisih untuk diambil dan didengar keterangan yang diperlukan;

3) Mengatur dan memimpin mediasi;

4) Membantu dan membuat perjanjian bersama, apabila mediasi berhasil tercapai;

5) Membuat anjuran tertulis apabila dalam hal mediasi tidak tercapai;

6) Membuat risalah penyelesaian perselisihan hubungan industrial;

7) Membuat laporan hasil penyelesaian perselisihan hubungan industrial;

8) Meminta surat-surat dan dokumen-dokumen yang diperlukan.

Apabila dikaitkan dengan teori kewenangan, maka terlebih dahulu kita harus melihat status mediator dalam perselisihan hubungan industrial. Di dalam Pasal 8 Undang-Undang Nomor 2 Tahun 2004 Tentang PPHI, secara tegas menyebut penyelesaian perselisihan melalui mediasi dilakukan oleh mediator yang berada di setiap kantor instantsi yang bertanggung jawab dibidang ketenagakerjaan kabupaten/kota, maka berdasarkan kewenangan yang melekat pada mediator hubungan industrial adalah wewenang atribusi. Dalam ajaran hukum administrasi negara, atribusi berkenaan dengan penyeraahan wewenang baru atau bila mana undang-undang (dalam arti materil) menyerahkan wewenang tertentu pada organ tertentu.

${ }^{23}$ Koesparmono Irsan dkk, Hukum Tenaga Kerja: Suatu Pengantar (Erlangga 2016).[125]. 
Sapta Imtinan, dkk: Kewenangan Mediator Pegawai...

Produk hukum yang dihasilkan dalam mediasi terbagi menjadi 2 jenis, yaitu Perjanjian Bersama dan Anjuran tertulis. Perjanjian bersama dibuat apabila dalam proses mediasi tersebut tercapai/berhasil mencapai kesepakatan antara para pihak yang bersengketa/berperkara, sedangkan anjuran tertulis dibuat apabila dalam proses mediasi tersebut gagal mencapai kesepakatan.

\section{Objek Sengketa dan Hasil Mediasi dalam Penyelesaian Perselisihan Hubungan Industrial}

Dalam Perselisihan sengketa Hubungan kerja sesuai dengan Undang-Undang Nomor 2 Tahun 2004 tentang Penyelesaian Perselisihan Hubungan industrial terdiri dari 4 perselisihan, yaitu, perselisihan hak, perselisihan kepentingan, perselisihan pemutusan hubungan kerja, dan perselisihan serikat pekerja.

1. Perselisihan Hak

Definisi perselisihan hak dijelaskan dalam Pasal 1 angka 2 UndangUndang Nomor 2 Tahun 2004 tentang Penyelesaian Perselisihan hubungan industrial dan juga Pasal 1 angka 5 Peraturan Menteri Ketenagakerjaan Nomor 17 Tahun 2014 tentang Pengangkatan dan Pemberhentian Mediator serta tata cara mediasi. Merujuk pada kedua pasal tersebut, definisi yuridis dari perselisihan hak adalah perselisihan yang timbul karena tidak dipenuhinya hak, akibat adanya perbedaan pelaksanaan atau penafsiran terhadap ketentuan penafsiran peraturan perundang-undangan, perjanjian kerja, peraturan perusahaan taupun perjanjian kerja bersama. Hak yang dimaksud di sini adalah hak normatif, yang mana hak tersebut sudah ditetapkan dalam perjanjian kerja bersama, peraturan perusahaan, maupun peraturan perundang-undangan. ${ }^{24}$

Perselisihan itu sendiri dapat terjadi dengan berlatar belakangi beberapa faktor penyebab sebagai berikut:

a. Tidak dipenuhinya hak sebagai akibat adanya perbedaan pelaksanaan

\footnotetext{
${ }^{24}$ Bambang Yunarko, 'Penyelesaian Perselisihan Hubungan Industrial melalui Lembaga Arbitrase' (2011) 1 Jurnal Perspektif.[2].
} 
atas ketentuan peraturan peruundang-undangan;

b. Tidak terpenuhinya hak sebagai akibat adanya perbedaan pelaksanaan aturan perjanjian kerja;

c. Tidak dipenuhinya hak sebagai akibat dari perbedaan pelaksanaan peraturan perusahaan;

d. Tidak dipenuhinya hak akibat perbedaan pelaksanaan ketentuan perjanjian kerja Bersama. ${ }^{25}$

Contoh nyata dari perselisihan ini, ketika pekerja/buruh menolak gaji yang diberikan oleh perusahaan karena para pihak memiliki definsi atau penafsiran tentang gaji yang berbeda-beda dari perjanjian kerja yang telah dibuat. Dalam hal ini, besaran gaji yang diberikan tidak sesuai dengan yang telah ditentukan dikontrak awal. Hal ini pun menjadi masalah yang selalu timbul antara pekerja dengan pihak perusahaan.

2. Perselisihan Kepentingan

Definisi Perselisihan Kepentingan adalah Perselisihan yang timbul karena adanya ketidaksesuaian pendapat mengenai pembuatan, dan / atau perubahan syarat-syarat kerja yang ditetapkan dalam perjanjian kerja bersama, atau peraturan perusahaan atau peraturan kerja bersama. Biasanya, jenis perselisihan ini terjadi ketika perusahaan mengubah isi dari perjanjian kerja tanpa persetujuan dari karyawannya. ${ }^{26}$ Unsur-unsur yang harus terpenuhi dalam perselisihan ini, antara lain adalah sebagai berikut:

a. Ada perselisihan;

b. Dalam hubungan kerja;

c. Tidak ada kesesuaian pendapat;

d. Mengenai pembuatan dan/atau perubahan syarat-syarat kerja;

e. Di dalam peraturan kerja, perjanjian kerja, maupun peraturan perusahaan. ${ }^{27}$

Contoh kasus:

${ }^{25}$ Yusuf Dedi Wibowo, “Hukum Ketenagakerjaan” 1.[289].

${ }^{26}$ et al Agus Mulya Karsona, 'Perspektif penyelesaian Sengketa Ketenagakerjaan Melalui Pengadilan Hubungan Industrial Dalam Menghadapi Masyarakat Ekonomi Asean' (2020) 2 Jurnal Hukum Poros Pajajaran.[122].

27 et all Hazar Kusmayanti, 'Penyelesaian Perselisihan Hubungan Industrial Melalui Putusan Perdamaian di Pengadilan Hubungan Industrial Pengadilan Negeri Padang Kelas I (A)’ (2020) 6 Adhaper.[26]. 
Sapta Imtinan, dkk: Kewenangan Mediator Pegawai...

Kasus Semen Holcim Cilacap pada Tahun 2013. Yang mana, dalam kasus tersebut, PT. Holcim Indonesia Tbk, yang beralamat di Jalan Ir.H.Juanda, Cilacap, selaku tergugat, dengan serikat buruh/pekerja nusantara, FSPSI, selaku penggugat. Di mana, dalam kasus ini, obyek yang diperselisihkan adalah mengenai persoalan pemberian bonus. Bonus sendiri merupakan pendapatan diluar upah, yang diberikan oleh perusahaan kepada karyawan atas prestasinya yang melebihi target yang telah ditentukan oleh perusahaan. Pada tahun 2009-2012, beban target yang diberikan perusahaan untuk pemberian bonus kepada tergugat masih relative stabil, yakni sebesar 10-15\%. Namun, pada tahun 2013, beban target yang diberikan bertambah, menjadi sebesar $36,8 \%$, yang mana oleh Tergugat beban tersebut dinaikkan secara sepihak tanpa persetujuan Penggugat.

3. Perselisihan Pemutusan Hubungan Kerja

Perselisihan pemutusan hubungan kerja adalah perselisihan yang timbul karena tidak adanya kesesuaian mengenai pengakhiran hubungan kerja yang dilakukan oleh salah satu pihak. Pemutusan hubungan kerja di sini, dilakukan oleh pihak perusahaan terhadap pekerjanya berdasarkan alasan-alasan yang diatur dalam Undang-Undang Nomor 13 Tahun 2003. ${ }^{28}$ Perselisihan pemutusan hubungan kerja terjadi apabila salah satu pihak tidak menyetujui pemutusan hubungan kerja secara sepihak atau pekerja tidak mendapatkan hak-haknya yang semestinya ketika mengalami pemutusan hubungan kerja. ${ }^{29}$

Contoh Kasus:

PHK 300 buruh PT. Arnots pada tahun 2018. Pada tahun 2018, PT.Arnots melakukan PHK terhadap karyawannya. Para buruh, yang jumlahnya sekitar

${ }^{28}$ Mashari, 'Model Penyelesaian Perselisihan Hubungan Industrial Non Litigasi Berbasis keadilan Sosial' (2012) 41 Jurnal Masalah-Masalah Hukum <https://ejournal.undip.ac.id/index. $\mathrm{php} / \mathrm{mmh} /$ article/view/5788>.[550].

${ }^{29}$ Khikmatul Fikriyah, 'Peran Mediator Dalam Penyelesaian Perselisihan Hubungan Industrial di Masa Pandemi Covid-19 (Studi Kasus: Dinas Tenaga Kerja Kabupaten Gresik) Perselisihan Hubungan Industrial di Masa Pandemi Covid-19 (Studi Kasus: Dinas Tenaga Kerja Kabupaten Gresik)' (2021) 1 Jurnal Inovasi Penelitian.[66]. 
300 orang, diajak berunding dan diminta untuk mengundurkan diri. Namun, sampai selesai perundingan, hanya segelintir pekerja yang menerima. Perusahaan berdalih melakukan pemutusan hubungan kerja dengan dalih efisiensi, namun tidak memberikan tanggapan pada saat para buruh menanyakan kondisi keuangan perusahaan. ${ }^{30}$

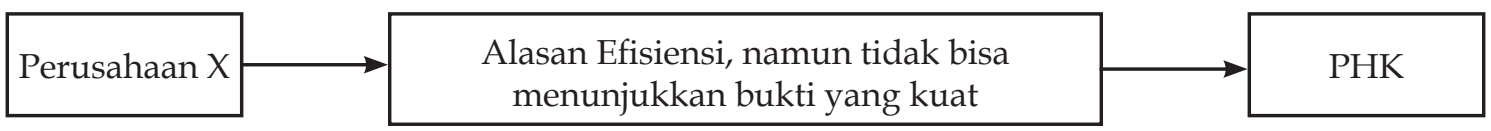

Bagan 1. Ilustrasi Pemutusan Hubungan Kerja

4. Perselisihan antar serikat pekerja / serikat buruh

Perselsisihan antara serikat pekerja/serikat buruh adalah perselisihan antara serikat pekerja/serikat buruh lain, hanya dalam satu perusahaan karena tidak ada kesesuaian mengenai keanggotaan, pelaksanaan hak dan kewjiban serikat pekerja/serikat buruh. Contoh: Perbedaan keanggotaan serikat buruh $\mathrm{X}$ dan serikat buruh $\mathrm{Y}$ dalam perusahaan. ${ }^{31}$

\begin{tabular}{|c|c|}
\hline $\begin{array}{c}\text { Serikat Buruh Perusahaan A } \\
\text { Serikat Buruh A } \\
\text { Serikat Buruh B } \\
\text { Serikat Buruh C }\end{array}$ & $\longrightarrow$ \\
Pelaksanaan hak dan kewajiban \\
\hline
\end{tabular}

Bagan 2. Ilustrasi Perselisihan Serikat Pekerja

\section{Hasil Mediasi}

Mediasi sendiri seperti yang kita ketahui bersama merupakan suatu bentuk penyelesaian sengketa tanpa melalui jalur/ melalui proses persidangan dipengadilan. Mediasi itu sendiri menjadi pilihan utama bagi para pihak dalam

${ }^{30}$ Andari Yurikosari Grace Angelia, ‘Perlindungan Hukum Terhadap Pekerja Akibat Pemutusan Hubungan Kerja (Phk) Sepihak Berdasarkan Undang-Undang Nomor 13 Tahun 2003 Tentang Ketenagakerjaan (Studi Putusan Pengadilan Negeri Bandung Nomor 211/Pdt.SusPhi/2018/Pn.Bdg)' (2020) 3 Jurnal Hukum Adigama.[5].

${ }^{31}$ Mashari, Op.Cit.[55]. 
Sapta Imtinan, dkk: Kewenangan Mediator Pegawai...

bersengketa dikarenakan keuntungan yang ditawarkan dari diadakannya mediasi itu sendiri ialah, hemat waktu, biayanya lebih murah karena dapat dinegosiasi oleh para pihak yang berperkara, dan yang palin penting adalah pilihan menyelesaikan sengketa melalui mediasi ialah adanya win to win solution. Akan tetapi mediasi juga selalu tergantung pada mediator dan kesepakatan antara para pihak untuk mencapai suatu jalan keluar yang bisa memberikan keuntungan atau rasa keadilan yang sama rata bagi masing-masing pihak. akan tetapi mediasi itu sendiri tidak selalu mencapai kesepakatan atau menemukan jalan keluar. Seperti yang sudah dikemukakan diatas bahwa dalam Undang-Undang Nomor 2 Tahun 2004 terdapat output dari proses mediasi itu adalah sebagai berikut:

1. Anjuran / Risalah Mediator

Anjuran/ Risalah Mediator dikeluarkan ketika proses mediasi mengalami kegagalan. Kewenangan mediator untuk mengeluarkan anjuran tertulis ini, tercantum dalam Pasal 13 Undang-Undang Nomor 2 Tahun 2004 tentang Penyelesaian Perselisihan Hubungan Industrial. Anjuran tertulis yang dikeluarkan oleh mediator harus sudah disampaikan kepada para pihak yang bersengketa selambat-lambatnya 10 hari sejak sidang mediasi yang pertama. Bagi para pihak yang menerima anjuran tertulis, wajib memberikan jawaban secara tertulis kepada mediator selambat-lambatnya 10 hari kerja sejak menerima anjuran tertulis. Pihak yang tidak memberikan pendapatnya, maka dianggap menolak anjuran tertulis. Namun, dalam hal para pihak menyetujui anjuran tertulis, maka dalam waktu selambat-lambatnya 3 hari kerja, mediator harus sudah selesai membantu para pihak membuat perjanjian bersama untuk selanjutnya didaftarkan pada Pengadilan Hubungan Industrial di wilayah hukum pihak-pihak membuat perjanjian bersama untuk mendapatkan akta pendaftaran.

Apabila Anjuran/Risalah mediator tersebut kemudian ditolak, maka berdasarkan ketentuan Pasal 14 Undang-Undang Nomor 2 Tahun 2004, para pihak atau salah satu pihak dapat melanjutkan penyelesaian perselisihan hubungan industrial tersebut ke Pengadilan Hubungan Industrial, yang mana 
proses penyelesaian melalui Pengadilan Hubungan Industrial tersebut harus dilakukan dengan pengajuan gugatan hubungan industrial.

2. Perjanjian Bersama / PB

Perjanjian Bersama merupakan produk hukum yang dikeluarkan oleh mediator, bilamana dalam proses mediasi tersebut, para pihak berhasil mencapai kesepakatan. Ketentuan Mengenai perjanjian bersama diatur dalam Pasal 13 Undang-Undang Nomor 2 Tahun 2004. Perjanjian Kerja bersama ditandatangani oleh para pihak dengan disasksian langsung oleh mediator untuk kemudian didaftarkan pada Pengadilan Hubungan Industrial pada Pengadilan Negeri di Wilayah Hukum para pihak membuat perjanjian kerja bersama untuk memperoleh akta pendaftaran.

Perjanjian Bersama memiliki kekuatan hukum eksekutorial, sehingga dalam hal ini, megandung implikasi bahwa ketentuan-ketentuan yang telah dicantumkan dalam Perjanjian Bersama tersebut harus dipatuhi dan dipenuhi oleh para pihak yang menandatangai perjanjian tersebut. Apabila isi dalam perjanjian bersama tersebut tidak dipatuhi oleh salah satu pihak, maka pihak yang dirugikan dapat mengajukan permohonan eksekusi kepada Pengadilan Hubungan Idustrial pada Pengadilan Negeri di Wilayah Hukum para pihak membuat perjanjian kerja bersama. Hal inilah yang membedakan Perjanjian Bersama dengan Risalah/ Anjuran. Perjanjian kerja bersama memiliki kekuatan eksekutorial, yang mana dapat diajukan permohonan eksekusi apabila salah satu pihak berniat melakukan mangkir.

\section{Batas Waktu Kewenangan Mediator}

Dalam menjalankan kewenangannya, mediator diberikan batas waktu untuk meyelesaikan tugasnya. Pasal 4 Ayat (4) Undang-Undang Nomor 2 Tahun 2004 memberikan ketentuan mediator menjalankan tugasnya dalam waktu selambatlambatnya 30 (tiga puluh) hari kerja terhitung sejak menerima pelimpahan penyelesaian perselisihan sebagaimana di maksud dalam Pasal 4 Ayat (4). Bagi mediator yang tidak dapat menyelesaikan perselisihan industrial dalam waktu 
Sapta Imtinan, dkk: Kewenangan Mediator Pegawai...

selambat-lambatnya 30 hari kerja tanpa alasan yang sah sebagaimana dimaksud dalam Pasal 15 Undang-undang Nomor 2 Tahun 2004 dapat dikenakan sanksi admininstrasi berupa hukuman disiplin sesuai dengan peraturan perundangundangan yang berlaku bagi PNS.

Tentunya, dalam pelaksanaan kewenangan, terdapat beberapa unsur yang melekat pada kewenangan. Menyitir pendapat Nur Basuki Minarno, dalam bukunya yang berjudul Penyalahgunaan Wewenang dan Tindak Pidana Korupsi dan Lukman Hakim dalam bukunya yang berjudul Filosofi Kewenangan Organ Lembaga Daerah Pemberian kewenangan juga mengisyaratkan adanya beberapa unsur, seperti: ${ }^{32}$

1. Konformitas, yaitu adanya standar wewenang, baik standar umum maupun standar khusus. ${ }^{33}$

2. Dasar Hukum, berkaitan dengan prinsip bahwa setiap wewenang harus dapat ditunjukkan dasar hukumnya. ${ }^{34}$

Lebih lanjut lagi, Safri Nugraha dan kawan-kawan, juga mengemukakan bahwa sifat kewenangan pemerintah selalu terikat pada tiga aspek, yaitu selalu terikat pada suatu masa tertentu, selalu terikat pada batas tertentu yang telah ditentukan, dan pelaksanaannya selalu terikat pada ketentuan hukum tertentu, baik yang tertulis maupun yang tidak tertulis, yang dalam hal ini termasuk juga asas-asas hukum pemerintahan yang baik..$^{35}$

Sehingga bilamana kewenangan tersebut, di dalam pelaksanaannya tidak digunakansebagaimana mestinya, dalam hal ini tidaksesuaidengansifat wewenang pemerintahan tersebut, maka tindakan atau kewenangan yang dilakukan tersebut bisa dikatakan tidak sah atau batal demi hukum. Selain itu, sifat kewenangan yang selalu terikat pada batasa wilayah kewenangan pemerintah atau kewenangan itu selalu tunduk pada batas kewenangan berkaitan erat dengan batas kewenadan batas cakupan materi kewenangan. Batas lingkup kewenangan terkait erat dengan

\footnotetext{
${ }^{32}$ Nandang Alamsyah, Teori Dan Praktek Kewenangan Pemerintah (UNPAD Press 2017).[13].

${ }^{33}$ ibid.[14].

34 ibid.

35 ibid. [15].
} 
ruang lingkup kompetensi absolut dari kewenangan pemerintah tersebut. ${ }^{36}$

Implikasi Yuridis yang terjadi terhadap mediator yang melampaui batas waktu terdapat dalam Pasal 22 Peraturan Menteri Tenaga Kerja dan Transmigrasi Nomor 17 Tahun 2014, yang mana dinyatakan bahwa terhadap mediator yang tidak dapat menyelesaikan perselsisihan hubungan industrial dalam waktu paling lama 30 hari tanpa alasan yang sah sebagaimana dimaksud dalam Pasal 15 ayat (1) dapat dikenakan hukuman administratif berupa hukuman disiplin sesuai dengan peraturan perundang-undangan yang berlaku bagi pegawai negeri sipil. Implikasi Yuridis Kewenangan Mediator, sebagaimana telah dibahas sebelumnya, diatur dalam Undang-Undang Nomor 2 Tahun 2004 dan juga Peraturan Menteri Ketenagakerjaan dan Transmigrasi Republik Indonesia Nomor 17 Tahun 2014.

Di dalam ajaran mengenai teori kewenangan, telah disebutkan beberapa jenis kewenangan tersebut diperoleh. Ada jenis kewenangan yang berupa mandat, atribusi dan juga delegasi. Untuk mengetahui karakteristik kewenagan mediator, terlebih dahulu harus dipahami bahwa dalam perselisihan hubungan industrial, mediator tidaklah ditunjuk oleh para pihak yang bersengketa, melainkan telah ditunjuk langsung dan disediakan oleh pemerintah. Hal ini tentunya berbeda dengan penyelesaian sengketa sebagaimana yang diatur dalam Undang-Undang Nomor 30 Tahun 1999, yang mana para pihak yang bersengketa diberikan kebebasan untuk memilih sendiri mediator yang dikehendaki.

Dalam kaidah Hukum Administrasi, kewenangan mediator dalam penyelesaian perselisihan hubungan industrial merupakan pemberian wewenang pemerintahan oleh pembuat undang-undang kepada organ pemerintahan dalam hal ini Dinas Ketenagakerjaan dan transmigrasi. Kewenangan yang demikian disebut sebagai wewenang atribusi. mediator selaku penerima kewenangan, akan mendapatkan sanksi administratif apabila mediator gagal menangani perselisihan hubungan industrial dalam waktu 30 hari sebagaimana yang diatur dalam Permenakertrans Nomor 17 Tahun 2014 tentang Pengangkatan dan Pemberhentian

\footnotetext{
${ }^{36}$ Aminuddin Ilmar, Hukum Tata Pemerintahan (Prenada Media 2017).[17].
} 
Sapta Imtinan, dkk: Kewenangan Mediator Pegawai...

Mediator Hubungan Industrial serta Tata Kerja Mediasi.

Implikasi yuridis terhadap pelaksanaan kewenangan ini, juga akan berdampak pada produk hukum yang nantinya akan dihasilkan oleh mediator, baik anjuran maupun perjanjian bersama. Dikarenakan kedua produk hukum ini merupakan pelaksanaan kewenangan dari mediator, maka tentunya produk hukum ini harus memenuhi ketiga unsur, yaitu selalu terikat pada masa tertentu, terikat pada batas waktu yang telah ditentukan, dan pelaksanaan kewenangan yang terikat pada ketentuan hukum tertentu, maka sudah pasti produk hukum yang dihasilkan akan batal demi hukum atau tidak sah.

Untuk studi kasus yang lebih jelas, penulis memberikan contoh kasus berupa penyelesaian sengketa hubungan industrial antara CV.Guna Makmur Abadi dengan karyawannya, yang bernama Nurhayati Bolonggudu. Nurhayati Bolonggudu terkena penyakit stroke karena kecelakaan kerja dan dirawat selama 1 minggu di RS Chasan Boesoeri. Tetapi pihak CV Guna Makmur Abadi tidak membayar upah beliau selama rentang waktu bulan September hingga Oktober 2019 dikarenakan pihak Nurhayati tidak mampu menunjukkan bukti sakit yang diderita. Akhirnya pada tanggal 10 Oktober 2019 pihak Nurhayati dengan pihak PT Guna Makmur Abadi. Pada perundingan tersebut, dicapailah kesepakatan dan diterbitkan risalah pada tanggal 18 Maret 2020. Risalah tersebut, apabila ditinjau dari ketentuan Peraturan Menteri Ketenagakerjaan dan Transmigrasi Nomor 17 tahun 2014, tentunya sudah melewati batas waktu yang ditentukan secara limitatif yaitu 30 hari. Maka, dalam hal ini, Mediator Hubungan Industrial telah melampaui kewenangannya, sehingga berakibat pada kekuatan risalah yang diterbitkan menjadi tidak sah.

Namun, dalam hal ini agaknya perlu kembali dipahami, bahwa dalam Pasal 22 Peraturan Menteri Ketenagakerjaan dan Transmigrasi Republik Indonesia Nomor 17 Tahun 2014 tentang Pengangkatan dan Pemberhentian Mediator Hubungan Industrial Serta Tata Cara Kerja Mediasi, dinyatakan ada frasa kata tanpa alasan yang sah. Sehingga dalam hal ini, perlu penafsiran ulang terhadap makna frasa tanpa alasan yang tersebut. 


\section{Kesimpulan}

Kewenangan mediator dalam penyelesaian perselisihan hubungan industrial termasuk dalam kewenangan yang bersifat atribusi karena pemberian wewenaang pemerintahan oleh pembuat undang-undang kepada organ pemerintahan in case mediator dinas tenaga kerja yang mana dalam pelaksanaaan kewenangan tersebut terikat dengan batas waktu tertentu, dan terikat pada ketentuan hukum selama 30 hari kerja. Tentu, pelaksanaan kewenangan tersebut, selama 30 hari merupakan hal yang harus dipatuhi, sehingga apabila tidak memenuhi ketentuan ataupun melebihi 30 hari, selain mendapatkan sanksi administratif bagi mediator, juga berpotensi melampauai kewenangan dan lebih jauh lagi mengakibatkan produk hukum yang dihasilkan tidak sah atau batal demi hukum. Sehingga dengan kasus yang telah diuraikan tersebut di atas dengan jangka waktu 5 bulan dalam penyelesaian perselisihan hubungan industrial telah menunjukkan bahwa mediator telah melampaui batas kewenangan yang telah ditentukan dalam Pasal 15 Peraturan Menteri Ketenagakerjaan dan Transmigrasi Nomor 17 Tahun 2014 tentang Pengangkatan dan Pemberhentian Mediator Hubungan Industrial Serta Tata Cara Kerja Mediasi, sehingga mediator tersebut selain diberikan sanksi administratrif juga berakibat terhadap produk hukum berupa anjuran atau risalah mediator menjadi tidak sah.

Namun, berdasarkan Ketentuan Pasal 22 Peraturan Menteri Ketenagakerjaan dan Transmigrasi Nomor 17 Tahun 2014 tentang Pengangkatan dan Pemberhentian Mediator Hubungan Industrial Serta Tata Cara Kerja Mediasi, terdapat frasa kata tanpa alasan yang sah, yang harus dipertimbangkan sebelum menjatuhkan sanksi bagi mediator yang melampaui jangka waktu yang diberikan.

\section{Daftar Bacaan}

\section{Buku}

Abdul Khakim, Aspek Hukum Penyelesaian Perselisihan Hubungan Industrial (Citra Aditya Bakti 2015).

Aminuddin Ilmar, Hukum Tata Pemerintahan (Prenada Media 2017). 
Sapta Imtinan, dkk: Kewenangan Mediator Pegawai...

Asri Wijayanti, Hukum Ketenagakerjaan Pasca Reformasi (2016).

Budiono AR, Hukum Perburuhan (2009).

Hernawan A, Penyelesaian Sengketa Hubungan Industrial (UII Press 2018).

HR R, Hukum Administrasi Negara (PT Raja Grafindo Persada 2013).

Khakim A, Aspek Hukum Penyelesaian Perselisihan Hubungan Industrial (2005).

Koesparmono Irsan dkk, Hukum Tenaga Kerja: Suatu Pengantar (Erlangga 2016).

Lia Lestari, 'Peran Mediator Dalam Penyelesaian Perselisihan Hubungan Industrial' (Program Pascasarjana Universitas Medan Area 2019).

Nandang Alamsyah, Teori Dan Praktek Kewenangan Pemerintah (UNPAD Press 2017).

Peter Mahmud Marzuki, Penelitian Hukum (Kencana Pranadamedia 2005).

- -, Penelitian Hukum (Kencana 2005).

Puji Ugo, Hukum Acara Penyelesaian Perselisihan Hubungan IndustriaL (Sinar Grafika 2011).

Ramli L, Hukum Ketenagakerjaan (Airlangga University Press 2008).

Ridwan HR H, Hukum Administrasi Negara (2012).

\section{Jurnal}

Agus Mulya Karsona et al, 'Perspektif penyelesaian Sengketa Ketenagakerjaan Melalui Pengadilan Hubungan Industrial Dalam Menghadapi Masyarakat Ekonomi Asean' (2020) 2 Jurnal Hukum Poros Pajajaran.

Andry Sugianti et al, 'Penyelesaian Perselisihan Hubungan Industrial Melalui Mediasi di Dinas Tenaga Kerja dan Transmigrasi Kota Semarang' (2016) 5 No. 2 http://www.ejournal-s1.undip.ac.id/index.php/dlr/ 7.

Bambang Yunarko, 'Penyelesaian Perselisihan Hubungan Industrial melalui Lembaga Arbitrase' (2011) 1 Jurnal Perspektif.

Grace Angelia AY, 'Perlindungan Hukum Terhadap Pekerja Akibat Pemutusan Hubungan Kerja (Phk) Sepihak Berdasarkan Undang-Undang Nomor 13 Tahun 2003 Tentang Ketenagakerjaan (Studi Putusan Pengadilan Negeri Bandung Nomor 211/Pdt.Sus-Phi/2018/Pn.Bdg)' (2020) 3 Jurnal Hukum 
Adigama.

Hazar Kusmayanti et all, ‘Penyelesaian Perselisihan Hubungan Industrial Melalui Putusan Perdamaian di Pengadilan Hubungan Industrial Pengadilan Negeri Padang Kelas I (A)' (2020) 6 Adhaper.

Khikmatul Fikriyah, 'Peran Mediator Dalam Penyelesaian Perselisihan Hubungan Industrial di Masa Pandemi Covid-19 (Studi Kasus : Dinas Tenaga Kerja Kabupaten Gresik) Perselisihan Hubungan Industrial di Masa Pandemi Covid-19 (Studi Kasus: Dinas Tenaga Kerja Kabupaten Gresik)' (2021) 1 Jurnal Inovasi Penelitian.

Mashari, 'Model Penyelesaian Perselisihan Hubungan Industrial Non Litigasi Berbasis keadilan Sosial' (2012) 41 Jurnal Masalah-Masalah Hukum <https:/ / ejournal.undip.ac.id/index.php/mmh/article/view/5788>.

Solechan, Suhartoyo AS, "Penyelesaian Perselisihan Hubungan Industrial melalui Mediasi di Dinas Tenaga Kerja dan Transmigrasi Kota Semarang" (2016) 5 DiponegoroLaw Review<https://www.neliti.com/id/publications/19005/ penyelesaian-perselisihan-hubungan-industrial-melalui-mediasi-di-dinastenaga-ke>.

How to cite: Sapta Imtinan Akmal, Juwita Sarri, Yanto Yunus, 'Kewenangan Mediator Pegawai Negeri Sipil Dalam Penyelesaian Perselisihan Hubungan Industrial’ (2022) Vol. 5 No. 1 Media Iuris. 
--Halaman ini sengaja dibiarkan kosong-- 